\title{
PERKEMBANGAN MANGROVE DAN PRODUKSI IKAN LAUT DI PATI UTARA
}

\section{THE GROWTH OF MANGROVE AND MARINE FISH PRODUCTION IN NORTHERN PATI}

\author{
Hermain Teguh Prayitno \\ Badan Perencanaan Pembangunan Daerah Kabupaten Pati \\ Email : hermainteguh70@gmail.com
}

Naskah Masuk: 18 Oktober 2017 Naskah Revisi: 25 Oktober $2017 \quad$ Naskah Diterima: 7 November 2017

\begin{abstract}
The fishing activities along the coastal area in Northern Pati potentially cause mangrove destruction. The objectives of this study were: (1) to discuss the growth of mangrove area in Northern Pati and (2) to describe the impact of the mangrove forest on marine fish production. This study used quantitative-descriptive research design. The study locations were Dukuhseti and Tayu subdistrict. It was conducted from August to September 2017. It used raster data obtained from Google Earth and Google Maps, formed Landsat 8 satellite images. The other was data of mangrove forest area in Pati Regency. The data analysis was conducted using the satellite images in 2011, 2013, 2015, and 2017. Then, the mangrove growth data were weighted and classified using scores. Validation was done by comparing the mangrove data from Statistic Agency of Pati Regency and those of the satellite image measuring results. The study concluded: (1) The mangrove forest in Northern Pati was in a poor condition. (2) The growth of mangrove forest fluctuated, which the lowest growth happened in 2013, while the highest was found in 2017. (3) The growth of mangrove forest was followed by the increase of marine fish production.
\end{abstract}

Keywords: mangrove, marine fish, north pati, satellite image

\section{ABSTRAK}

Kabupaten Pati berada di bagian utara Pulau Jawa memiliki aktivitas masyarakat sebagai pertambak dan nelayan. Penambahan tambak ke arah laut menyebabkan kerusakan mangrove. Tujuan penelitian ini adalah : (1) untuk mengetahui pertumbuhan mangrove di pesisir Pati utara dan (2) untuk menggambarkan dampak hutan mangrove terhadap produktivitas ikan laut. Penelitian ini merupakan penelitian deskriptif kuantitatif. Lokasi penelitian yaitu Kecamatan Dukuhseti dan Kecamatan Tayu. Waktu Penelitian Agustus sampai dengan September 2017. Sumber data berasal dari data raster dari Google Earth dan Google Maps berupa image satelit Landsat 8. Data lain yaitu data luas hutan mangrove di Kabupaten Pati. Analisis data dengan pengukuran image satelit tahun 2011, 2013, 2015 dan 2017. Selanjutnya data perkembangan mangrove dilakukan pembobotan dan diklasifikasikan berdasarkan skor. Verifikasi hasil dilakukan dengan cara membandingkan data perkembangan mangrove dari BPS Kabupaten Pati dengan hasil pengukuran image satelit. Hasil penelitian yaitu (1) hutan mangrove di Pati utara dalam kondisi berkembang buruk. (2) Perkembangan hutan mangrove fluktuatif, dimana perkembangan terendah terjadi pada 2013, sedangkan perkembangan tertinggi pada 2017; 2) perkembangan mangrove di Pati utara mengalami penurunan pada tahun 2013 dan meningkat kembali pada tahun 2015 dan 2017. (3) Perkembangan mangrove diiringi dengan peningkatan produksi ikan segar di Pati Utara.

Kata kunci : mangrove, ikan laut, pati utara, image satelit 


\section{PENDAHULUAN}

Kabupaten Pati terletak dibagian utara Pulau Jawa. Sebelah utara berbatasan dengan Kabupaten Jepara dan Laut Jawa, sebelah selatan berbatasan dengan Kabupaten Grobogan dan Kabupaten Blora, sebelah Barat berbatasan dengan Kabupaten Kudus dan Kabupaten Jepara, dan sebelah timur berbatasan dengan Kabupaten Rembang dan Laut Jawa (BPS Kab. Pati, 2016). Panjang garis pantai $\pm 60 \mathrm{Km}$ (Damayanti, 2011) dengan struktur tanah liat, sehingga di pesisir pantai terdapat pertambakan.

Masyarakat

pesisir menggantungkan hidupnya pada pantai dan laut. Pantai dan laut menjadi urat nadi kehidupan masyarakat, sehingga kualitas lingkungan pesisir harus dijaga kelestariannya. Penurunan kualitas lingkungan pesisir diindikasikan dengan kerusakan mangrove. Hutan mangrove memiliki nilai ekonomis dan ekologis yang tinggi, tetapi sangat rentan terhadap kerusakan. Kondisi hutan mangrove pada umumnya memiliki tekanan berat sebagai akibat dari tekanan krisis ekonomi yang berkepanjangan (Novianty dkk, 2012). Salah satu tekanan terhadap hutan mangrove adalah alih fungsi hutan mangrove seperti yang terjadi di kabupaten Pati. Hal ini akan berpengaruh buruk terhadap perekonomian nelayan, petambak, dan masyarakat lainnya. Kerusakan mangrove berdasarkan penelitian Jumaedi (2016) di wilayah kota Singkawang adalah alih fungsi menjadi tambak, hal ini disebabkan oleh : (1) tingginya kebutuhan ekonomi dan kurangnya kesadaran kepentingan ekologis serta kepedulian masyarakat akan dampak lingkungan, (2) kurangnya pemahaman masyarakat pentingnya penetapan Zona Sabuk Hijau (Green Belt) mangrove untuk kelestarian lingkungan, (3) rendahnya kesadaran masyarakat tentang konversi dan fungsi ekosistem mangrove.

Ekosistem hutan mangrove bersifat kompleks dan dinamis, namun labil. Kekomplekan ekosistem ini terlihat bahwa hutan mangrove menyumbangkan konstribusi besar detritus organik yang mendukung jaring makanan dalam ekosistem. Tingginya kelimpahan makanan dan tempat tinggal, serta rendahnya tekanan predasi, menyebabkan ekosistem mangrove membentuk habitat yang ideal untuk berbagai spesies satwa dan biota perairan, untuk sebagian atau seluruh siklus hidup mereka. Oleh karena itu, mangrove dapat berfungsi sebagai tempat pengasuhan yang penting untuk kepiting, udang dan berbagai jenis ikan, dan mendukung keberadaan populasi ikan lepas pantai dan perikanan (Wardhani, 2011). Secara fisik, kawasan mangrove menyediakan jasa lingkungan yang sangat besar yaitu perlindungan pantai dari badai dan erosi (Wardhani, 2011). Fungsi hutan mangrove sebagai perlindungan dari badai dan erosi yaitu dengan sabuk hijau (Green Belt). Penentuan lebar sabuk hijau dengan Keputusan Presiden No.32 tahun 1990 tentang Pengelolaan Kawasan Lindung. Keppres tersebut menetapkan bahwa perlindungan terhadap sempadan pantai dilakukan untuk melindungi wilayah pantai dari kegiatan yang mengganggu kelestarian fungsi pantai, dimana kriteria sempadan pantai yang dimaksud adalah daratan sepanjang tepian yang lebarnya proporsional dengan bentuk dan kondisi pantai, minimum $100 \mathrm{~m}$ dari titik pasang tertinggi ke arah darat. Selanjutnya, berdasarkan hasil kajian ekologis 
disarankan lebar sabuk hijau pada kawasan pantai berhutan mangrove minimal selebar 130 dikalikan nilai ratarata perbedaan antara air pasang tertinggi dan terendah tahunan yang diukur dari air surut terendah ke arah daratan.

Ekosistem mangrove dipengaruhi oleh kondisi perairan yang berubah setiap saat. Hal ini memberikan pengaruh terhadap biota perairan yang hidup berasosiasi dengan ekosistem mangrove tersebut. Yuniarti (2007) menyatakan bahwa wilayah pesisir merupakan lingkungan bahari yang produktif yang dapat dimanfaatkan secara langsung maupun tidak langsung. Potensi mangrove sebagai sumber nutrien bagi biota yang hidup di dalamnya sebagai tempat tinggal, tempat mencari makan (feeding ground), tempat pengasuhan dan pembesaran (nursery ground) serta tempat pemijahan (spawning ground). Keterkaitan ekosistem mangrove dengan sumberdaya ikan telah di buktikan oleh Paw dan Chua dalam Kawaroe (2001) yang melakukan penelitian di Filipina, dan menemukan hubungan positif antara area mangrove dan penangkapan udang penaeid. Di Indonesia, Martosubroto dan Naamin dalam Kawaroe (2001) membuktikan hubungan yang positif antara hasil tangkapan udang tahunan dan luas mangrove di seluruh Indonesia.

Sari dkk (2013) dalam penelitiannya menyatakan bahwa pemanfaatan hutan mangrove sebagai alih fungsi lahan mengakibatkan turunnya produktivitas hutan mangrove di pesisir Kota Rebah. Peralihan fungsi tersebut merusak mangrove dan mengganggu kehidupan biota di dalamnya. Latar belakang tersebut menjadi dasar dilakukannya penelitian di Kabupaten Pati. Permasalahan penelitian ini adalah kerusakan lingkungan pesisir dan keluhan nelayan tentang rendahnya tangkapan ikan di pantai Pati utara, sehingga tujuan penelitian ini (1) untuk mengetahui pertumbuhan mangrove di pesisir Pati utara dan (2) dampaknya terhadap produktivitas ikan laut.

\section{METODE PENELITIAN}

Penelitian ini merupakan penelitian deskriptif dengan pendekatan kuantitatif. Lokasi penelitian di Pesisir Pantai Pati Utara yaitu Kecamatan Dukuhseti dan Kecamatan Tayu. Waktu Penelitian bulan Agustus sampai bulan September 2017. Sumber data berupadata sekunder yaitu data raster yang diperoleh dari Google Earth dan Google Maps berupa image satelit Landsat 8 dengan resolusi 15 meter. Data lain yaitu data luas hutan mangrove di Kabupaten Pati dari BPS Kabupaten Pati.

Pengolahan data luas mangrove dilakukan melalui pengukuran lebar atau tebal mangrove dari Desa Puncel Kecamatan Dukuhseti sampai dengan Desa Sambiroto Kecamatan Tayu pada image satelit tahun 2011. Pengulangan pengukuran dilakukan untuk tahun 2013, 2015 dan 2017. Untuk mengetahui lokasi desa dan Kecamatan pengamatan dengan cara overlay koordinat lokasi image di google earth terhadap image lokasi di google maps.. Pengukuran image dimulai dari muara kali Puncel menuju ke timur sampai di muara kali Tayu. Titik pertama merupakan kilometer nol, untuk titik kedua dan selanjutnya sampai titik terakhir di muara kali Tayu diberi interval jarak satu kilometer (20 lokasi pengukuran). Pengukuran menggunakan toolbar ruler pada menu google earth, baik line maupun path. 


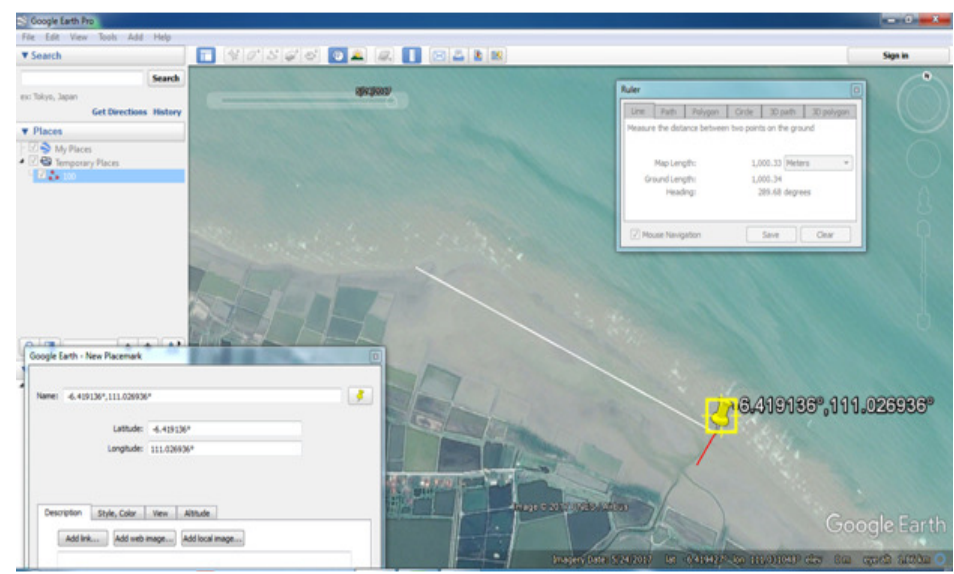

Gambar 1.

Cara Penentuan Lokasi Sampel

Sumber : Pengolahan Data (2017)

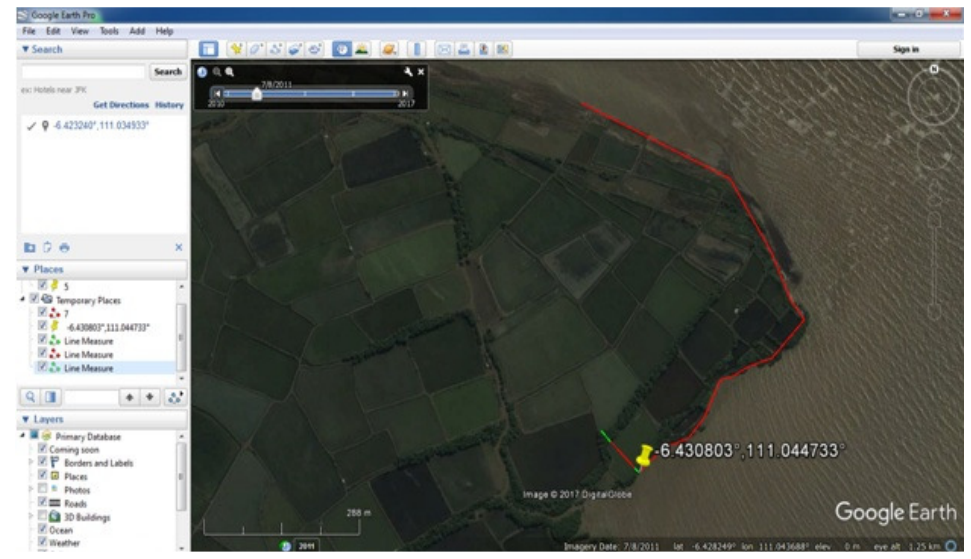

Gambar 2.

Cara Penentuan Lokasi Sampel Pantai Berbelok

Sumber : Pengolahan Data (2017)

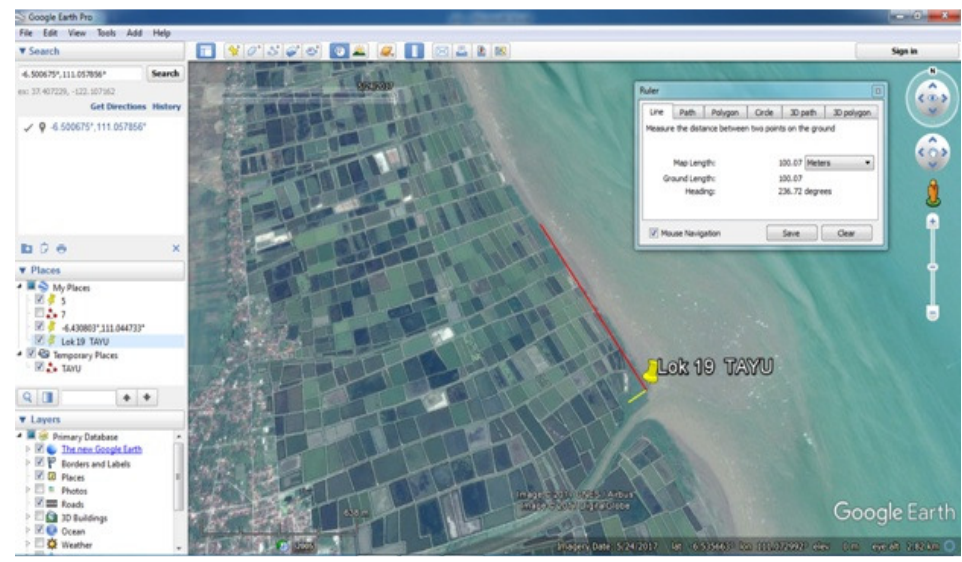

Gambar 3.

Lokasi Sampel Terakhir

Sumber : Pengolahan Data (2017) 
Pengolahan data yaitu menentukan lokasi batas basah pantai dimana terdapat rona gelap tanah kering dan warna jernih tanah basah. Lokasi batas ini berbeda setiap tahun tergantung adanya abrasi dan akresi pantai. Penentuan titik ini untuk mengukur mangrove meter pertama sampai meter berikutnya, baik yang langsung sepanjang 100 meter maupun yang berselang ke arah darat. Pencatatan tebal mangrove setiap lokasi dan setiap tahun mulai dari tahun 2011, 2013, 2015, dan 2017. Data yang telah diperoleh kemudian dilakukan pembobotan. Pembobotan dengan nilai bobot tertinggi yaitu terdekat dengan laut. Rincian nilai bobot disajikan pada Tabel 1.

Skor perkembangan mangrove diperoleh dari perkalian bobot dengan tebal mangrove dibagi 100. Klasifikasi perkembangan mangrove berdasarkan skor yang diperoleh disajikan pada Tabel 2. Verifikasi hasil dilakukan dengan cara membandingkan data perkembangan mangrove dari BPS Kabupaten Pati tahun 2011-2015 (2016 belum dipublikasikan) dengan hasil pengukuran image satelit google earth tahun 2011, 2013, 2015 dan 2017.

Tabel 1.

Rincian Nilai Bobot Berdasarkan Tebal Mangrove

\begin{tabular}{ccc}
\hline No & Tebal Mangrove (meter) & Nilai Bobot \\
\hline 1 & $1-20$ & 5 \\
2 & $21-40$ & 4 \\
3 & $41-60$ & 3 \\
4 & $61-80$ & 2 \\
5 & $81-100$ & 1 \\
\hline
\end{tabular}

Sumber : Pengolahan Data, 2017

Tabel 2.

Klasifikasi Perkembangan Mangrove

\begin{tabular}{cccc}
\hline No & Kategori & Interval Bobot & Skor \\
\hline 1 & Berkembang baik & $2,01-3,00$ & 3 \\
2 & Berkembang sedang & $1,01-2,00$ & 2 \\
3 & Berkembang Buruk & $0,00-1,00$ & 1 \\
\hline \multicolumn{2}{l}{ Sumber : Pengolahan Data, 2017 }
\end{tabular}

\section{HASIL DAN PEMBAHASAN}

\section{Perkembangan Mangrove di Wilayah Pati Utara}

Perkembangan mangrove di Kabupaten Pati khususnya di wilayah Pati Utara mulai tahun 2011 sampai 2015 disajikan pada Tabel 3. Secara umum dari data perkembangan mangrove pada
Tabel 3 menunjukkan adanya peningkatan dari tahun 2011 sampai tahun 2012, pada tahun 2013 mengalami penurunan dan mengalami peningkatan kembali tahun 2014 sampai tahun 2015. Khusus Kecamatan yang masuk dalam lokasi penelitian ini yaitu Tayu dan Dukuhseti memiliki kondisi sangat berbeda. 
Tabel 3.

Luas Hutan Magrove di Kabupaten Pati

\begin{tabular}{lrrrrr}
\hline \multirow{2}{*}{ Lokasi } & \multicolumn{6}{c}{ Tahun ( Ha ) } \\
\cline { 2 - 6 } & $\mathbf{2 0 1 1}$ & $\mathbf{2 0 1 2}$ & $\mathbf{2 0 1 3}$ & $\mathbf{2 0 1 4}$ & $\mathbf{2 0 1 5}$ \\
\hline Batangan & 26,60 & 26,00 & 32,23 & 32,23 & 32,32 \\
Juwana & 4,40 & 8,00 & 39,14 & 39,14 & 39,14 \\
Wedarijaksa & 17,90 & 34,00 & 20,78 & 20,78 & 20,78 \\
Trangkil & 11,70 & 35,00 & 21,75 & 21,75 & 21,75 \\
Tayu & 9,75 & 22,14 & 2,14 & 5,89 & 22,14 \\
Dukuhseti & 46,05 & 20,71 & 20,71 & 20,71 & 20,71 \\
\hline Rata-rata & 303,91 & 308,26 & 307,11 & 307,79 & 310,26 \\
\hline Sumber : BPS Kab. Pati, 2012-2016
\end{tabular}

Kecamatan Tayu tahun 2011 luas hutan mangrove 9,75 Ha meningkat menjadi 22,14 Ha pada tahun 2012; turun pada tahun 2013 seluas $20 \mathrm{Ha}$ menjadi 2,14 Ha; pada tahun 2014 meningkat 3,75 Ha menjadi 5,89 $\mathrm{Ha}$; kemudian meningkat kembali tahun 2015, $25 \mathrm{Ha}$ menjadi 22,14 Ha. Luas hutan mangrove di Kecamatan Dukuhseti pada tahun 2012 mengalami penurunan sebesar 25,34 Ha dari luas semula 46,05 $\mathrm{Ha}$ menjadi 20,71 Ha. Tahun 2013 sampai 2015 luas hutan mangrove di Kecamatan Dukuhseti stabil yaitu 20,71 Ha.

Hasil pengukuran dengan image satelit setelah dilakukan pembobotan disajikan pada Tabel 4. Selama 6 tahun mulai tahun 2011, nilai rata-rata terendah perkembangan hutan mangrove terdapat pada 15 dari 20 lokasi. Pengamatan lokasi rerata terendah yaitu lokasi nomor $10,6,5,2,15,16,4,18,14,13,11,3$, 12, 7, dan 17. Pertumbuhan rata-rata sedang di lokasi nomor 9, 19, dan 20.

Pertumbuhan rata-rata tertinggi di lokasi nomor 1 dan 8. Pertumbuhan ratarata terendah (tahun 2017) adalah 0,00 berada di lokasi 10 di Desa Banyutowo dengan koordinat $6,448^{\circ} \mathrm{LS} 111,046^{\circ} \mathrm{BT}$ (Gambar 4). Hal serupa juga terdapat pada lokasi 5, dimana pertumbuhan mangrove adalah 0,00 (tahun 2017).

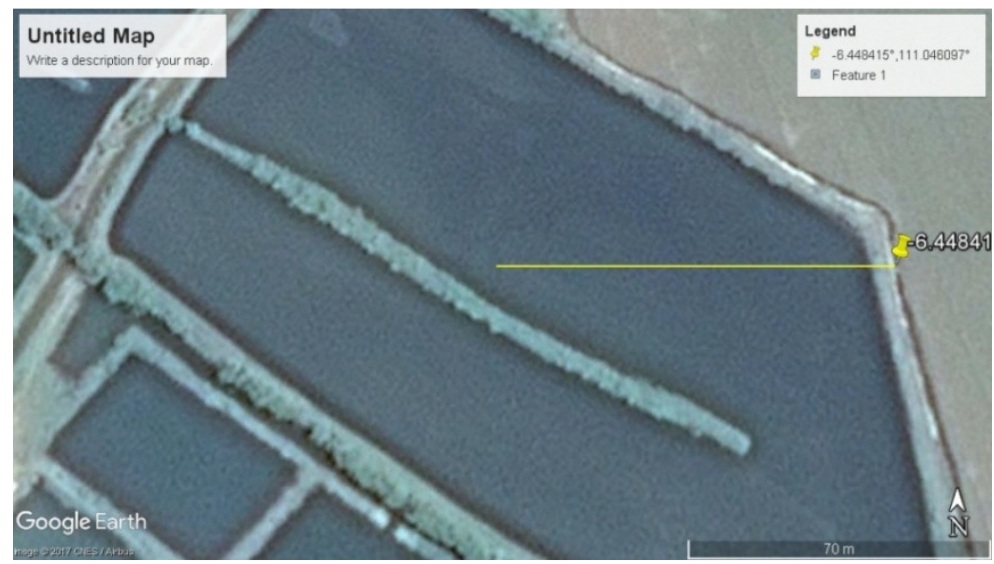

Gambar 4.

Lokasi Sampel 10

Sumber : Pengolahan Data (2017) 
Tabel 4.

Perkembangan Hutan Magrove di Pati Utara

\begin{tabular}{|c|c|c|c|c|c|c|c|c|c|}
\hline \multirow{2}{*}{ No } & \multirow{2}{*}{$\mathbf{K m}$} & \multirow{2}{*}{ Koordinat (LS; BT) } & \multicolumn{4}{|c|}{ Tahun Pengamatan } & \multirow{2}{*}{$\begin{array}{c}\begin{array}{c}\text { Rata- } \\
\text { rata }\end{array} \\
6 \text { th } \\
\end{array}$} & \multirow{2}{*}{\multicolumn{2}{|c|}{ Keterangan }} \\
\hline & & & 2011 & 2013 & 2015 & 2017 & & & \\
\hline \multirow[t]{2}{*}{1} & \multirow[t]{2}{*}{0} & \multirow[t]{2}{*}{$6,410290^{\circ} ; 110,975376^{\circ}$} & \multirow[t]{2}{*}{2,94} & \multirow[t]{2}{*}{2,65} & \multirow[t]{2}{*}{2,20} & \multirow[t]{2}{*}{0,96} & \multirow[t]{2}{*}{2,19} & \multicolumn{2}{|c|}{ Desa Puncel Kec Dukuhseti } \\
\hline & & & & & & & & Desa $\quad$ Puncel & Kecamatan \\
\hline \multirow[t]{2}{*}{2} & \multirow[t]{2}{*}{1} & \multirow[t]{2}{*}{$6,412621^{\circ} ; 110,983823^{\circ}$} & \multirow[t]{2}{*}{0,00} & \multirow[t]{2}{*}{0,00} & \multirow[t]{2}{*}{0,00} & \multirow[t]{2}{*}{0,52} & \multirow[t]{2}{*}{0,13} & Dukuhseti & \\
\hline & & & & & & & & Desa Tegalombo & Kecamatan \\
\hline 3 & 2 & $6,414112^{\circ} ; 110,992663^{\circ}$ & 1,12 & 0,00 & 0,00 & 1,41 & 0,63 & Dukuhseti & \\
\hline & & & & & & & & Desa Tegalombo & Kecamatan \\
\hline 4 & 3 & $6,415809^{\circ} ; 111,001577^{\circ}$ & 0,59 & 0,00 & 0,00 & 0,49 & 0,27 & Dukuhseti & \\
\hline & & & & & & & & Desa Kembang & Kecamatan \\
\hline 5 & 4 & $6,418745^{\circ} ; 111,019100^{\circ}$ & 0,40 & 0,00 & 0,00 & 0,00 & 0,10 & Dukuhseti & \\
\hline & & & & & & & & Desa Kembang & Kecamatan \\
\hline 6 & 5 & $6,423240^{\circ} ; 111,034933^{\circ}$ & 0,00 & 0,00 & 0,00 & 0,25 & 0,06 & Dukuhseti & \\
\hline & & & & & & & & Desa Kembang & Kecamatan \\
\hline 7 & 6 & $6,425931^{\circ} ; 111,043489^{\circ}$ & 0,00 & 0,60 & 0,81 & 1,40 & 0,70 & Dukuhseti & \\
\hline & & & & & & & & Desa Dukuhseti & Kecamatan \\
\hline 8 & 7 & $6,430803^{\circ} ; 111,044733^{\circ}$ & 2,88 & 2,88 & 2,88 & 2,88 & 2,88 & Dukuhseti & \\
\hline & & & & & & & & Desa Dukuhseti & Kecamatan \\
\hline 9 & 8 & $6,439837^{\circ} ; 111,044641^{\circ}$ & 1,58 & 1,39 & 1,39 & 1,39 & 1,44 & Dukuhseti & \\
\hline & & & & & & & & Desa Banyutowo & Kecamatan \\
\hline 10 & 9 & $6,448415^{\circ} ; 111,046097^{\circ}$ & 0,00 & 0,00 & 0,00 & 0,00 & 0,00 & Dukuhseti & \\
\hline & & & & & & & & Desa Banyutowo & Kecamatan \\
\hline 11 & 10 & $6,456579^{\circ} ; 111,048013^{\circ}$ & 0,50 & 0,50 & 0,50 & 0,50 & 0,50 & Dukuhseti & \\
\hline & & & & & & & & Desa Banyutowo & Kecamatan \\
\hline 12 & 11 & $6,465470^{\circ} ; 111,049922^{\circ}$ & 0,00 & 0,31 & 0,93 & 1,37 & 0,65 & Dukuhseti & \\
\hline & & & & & & & & Desa Alasdowo & Kecamatan \\
\hline 13 & 12 & $6,474483^{\circ} ; 111,050700^{\circ}$ & 0,00 & 0,42 & 0,00 & 1,35 & 0,44 & Dukuhseti & \\
\hline & & & & & & & & Desa Kenanti & Kecamatan \\
\hline 14 & 13 & $6,483283^{\circ} ; 111,052592^{\circ}$ & 0,00 & 0,00 & 0,68 & 0,72 & 0,35 & Dukuhseti & \\
\hline & & & & & & & & Desa Kenanti & Kecamatan \\
\hline 15 & 14 & $6,492097^{\circ} ; 111,055282^{\circ}$ & 0,00 & 0,00 & 0,00 & 0,82 & 0,21 & Dukuhseti & \\
\hline & & & & & & & & Desa Bakalan & Kecamatan \\
\hline 16 & 15 & $6,500675^{\circ} ; 111,057856^{\circ}$ & 0,00 & 0,37 & 0,00 & 0,55 & 0,23 & Dukuhseti & \\
\hline & & & & & & & & Desa Kalikalong & Kecamatan \\
\hline 17 & 16 & $6,509489^{\circ} ; 111,059544^{\circ}$ & 1,71 & 0,42 & 0,00 & 0,95 & 0,77 & Tayu & \\
\hline & & & & & & & & Dororejo & Kecamatan \\
\hline 18 & 17 & $6,517553^{\circ} ; 111,063535^{\circ}$ & 0,00 & 0,00 & 0,59 & 0,68 & 0,32 & Tayu & \\
\hline & & & & & & & & Dororejo & Kecamatan \\
\hline 19 & 18 & $6,525938^{\circ} ; 111,067338^{\circ}$ & 0,18 & 0,72 & 2,02 & 1,60 & 1,13 & Tayu & \\
\hline & & & & & & & & Desa Sambiroto & Kecamatan \\
\hline 20 & 19 & $6,534182^{\circ} ; 111,072352^{\circ}$ & 0,00 & 0,00 & 3,00 & 3,00 & 1,50 & Tayu & \\
\hline & & Rata-rata & 0,60 & 0,51 & 0,75 & 1,04 & 0,73 & $\begin{array}{l}\text { Lokus Pati Utara } \\
\text { s/d Sambiroto }\end{array}$ & Ds Punce \\
\hline
\end{tabular}

Sumber : Pengolahan Data, 2017

Gambar 4 menunjukkan bahwa lokasi 10 berada di area tambak yang berdekatan dengan garis pantai, sehingga tidak memungkinkan untuk ditanami mangrove atau jika ditanami akan sulit berkembang karena terhalang tanggul tambak.
Hal berbeda dapat dilihat di lokasi 2. Jika pada tahun 2011 tidak terdapat mangrove disekitar area tambak, maka perubahan terjadi di tahun 2017 yaitu sekitar area tambak mulai ditanami mangrove seperti ditunjukkan pada Gambar 5. 

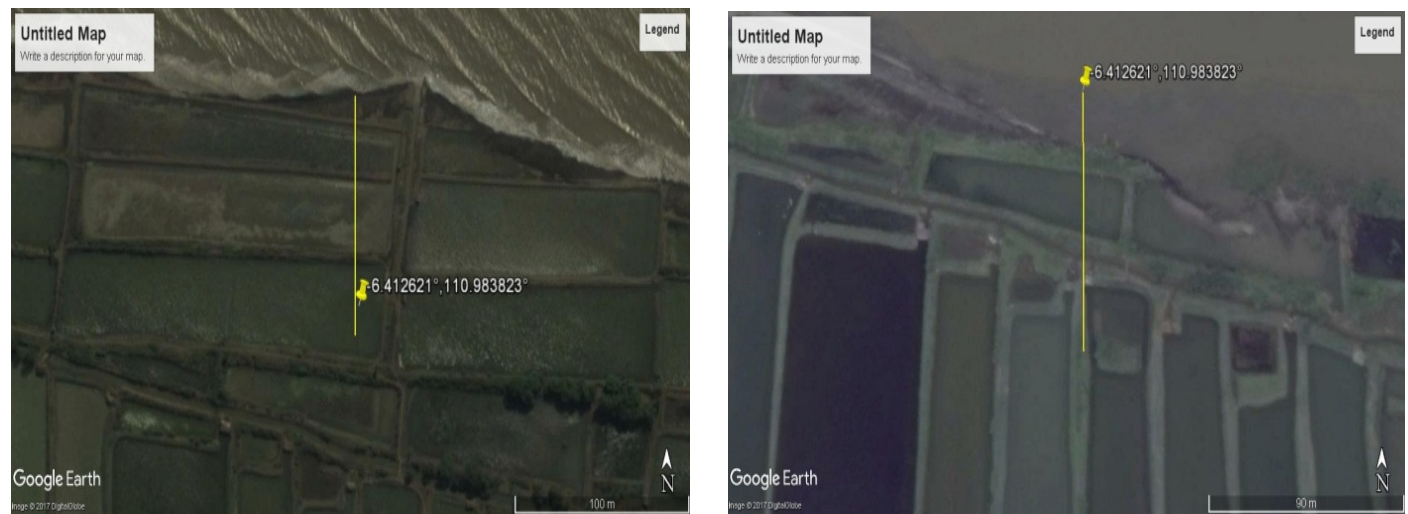

Gambar 5.

Lokasi Sampel 2 Tahun 2011 (Kanan) dan Tahun 2017 (Kiri)

Sumber : Pengolahan Data (2017)

Lokasi 2 dengan koordinat $6,412621^{\circ} \mathrm{LS}$ dan $110,983823^{\circ} \mathrm{BT}$ pada tahun 2011 berada di dalam tambak dikarenakan adanya akresi batas pasang surut 90 meter ke arah laut dan pada saat itu tidak memiliki mangrove. Abrasi terjadi sampai lokasi 2 dan mulai ditanami mangrove sebelum tahun 2017. Penanaman mangrove lokasi 2 dimulai dari meter ke 21 sampai meter ke 23 dengan panjang mangrove 13 meter. Hasil pembobotan lokasi 2 diperoleh nilai 0,55. Nilai ini berasal dari perhitungan 3 meter pertama dikalikan bobot dekat dengan laut bernilai 5. Untuk 10 meter berikutnya dikalikan bobot 4 sehingga nilai total 55 dibagi 100 menjadi 0,55 . Nilai bobot 0,55 termasuk dalam kategori berkembang buruk (skor 1). Akan tetapi, kondisi ini lebih baik dari tahun sebelumnya yang tidak memiliki mangrove sama sekali.

Perkembangan rata-rata sedang yaitu di lokasi 9 di Desa Dukuhseti, lokasi 19 di Desa Dororejo, dan lokasi 20 di Desa Sambiroto. Lokasi nomer 18 di Desa Dororejo dijelaskan pada Gambar 6.

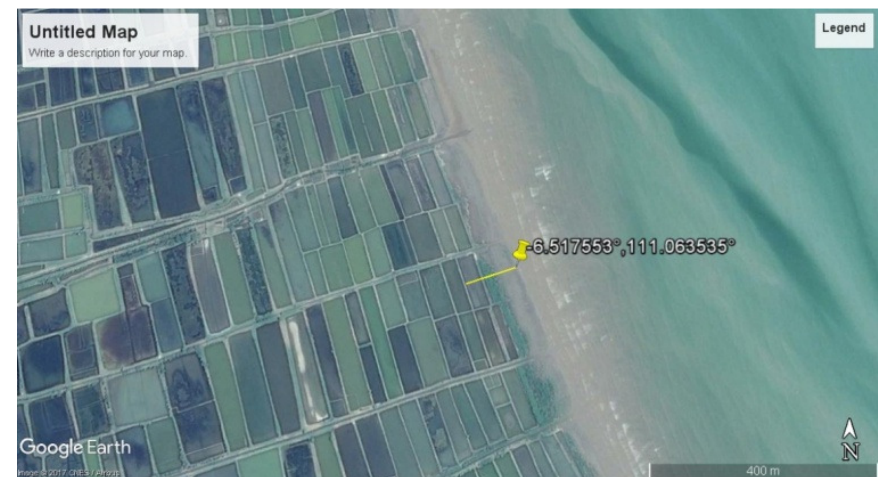

Gambar 6.

Lokasi Sampel 18

Sumber : Pengolahan Data (2017)

Lokasi 18 mulai memiliki sepanjang 24 meter dengan nilai mangrove pada tahun 2015 sepanjang 15 perkembangan 0,59 menjadi 0,68 . meter dan berkembang pada tahun $2017 \quad$ Perkembangan mangrove di lokasi 18 
akan sulit membentuk area green belt sepanjang 100 meter terukur kearah darat karena terdapat tambak yang menghalangi laju pertumbuhannya. Lokasi dengan nilai rata-rata tertinggi terdapat di lokasi 1 Desa Puncel dan lokasi 8 di Desa Dukuhseti dengan nilai 2,19 dan 2,88 termasuk dalam kategori berkembang baik (skor 3). Hasil perhitungan perkembangan mangrove dengan image satelit menunjukkan bahwa lokasi 20 memiliki angka pertumbuhan tertinggi yaitu 3,00. Pengamatan selama data 6 tahun dengan image satelit dan kondisi lokasi 20 pada tahun 2011 dan 2013 memiliki magrove relatif tebal tetapi jaraknya dengan laut di atas 100 meter, sehingga tidak dapat dinilai sehingga rata-rata selama 6 tahun lokasi 20 adalah 1,500 termasuk kategori berkembang sedang (skor 2). Secara umum rata-rata perkembangan mangrove selama 6 tahun bernilai rendah yaitu 0,73. Penurunan dimulai tahun 2013 yaitu nilai 0,51 meningkat sampai 1,04 pada tahun 2017. Kondisi terakhir yaitu berkembang sedang. Hal ini ditunjang oleh lokasi strategis muara kali, antara lain muara Kali Puncel dan Kali Tayu.

Verifikasi terhadap perhitungan perkembangan hutan mangrove di Pati Utara dilakukan dengan melihat perkembangan (pertumbuhan) hutan mangrove dari data perkembangan hutan mangrove berdasarkan data BPS Kab. Pati dibandingkan dengan data hasil pengukuran image satelit. Hasil verifikasi disajikan pada Tabel 5 .

Tabel 5.

Verifikasi Perkembangan Hutan Magrove di Pati Utara

\begin{tabular}{ccc}
\hline \multirow{2}{*}{ Tahun } & \multicolumn{2}{c}{ Perkembangan Hutan Mangrove } \\
\cline { 2 - 3 } & $\begin{array}{c}\text { Luas Hutan Mangrove (BPS Kab. } \\
\text { Pati) }\end{array}$ & $\begin{array}{c}\text { Luas Hutan Mangrove (Pengukuran } \\
\text { Image Satelit) }\end{array}$ \\
\hline 2011 & - & - \\
2013 & Meningkat & Menurun \\
2015 & Meningkat & Meningkat \\
2017 & Meningkat & Meningkat \\
\hline
\end{tabular}

Sumber : Pengolahan Data, 2017

Tabel 5 menunjukkan bahwa terdapat perbedaan perkembangan mangrove pada tahun 2013 berdasarkan data dari BPS Kab. Pati dan hasil pengukuran image satelit. Jika pada data BPS Kab. Pati pada tahun 2013 perkembangan hutan mangrove meningkat, sebaliknya hasil pengukuran menunjukkan bahwa perkembangan hutan mangrove mengalami penurunan. Hal ini dapat disebabkan karena pendataan luas hutan mangrove diduga tercatat saat dilaksanakan program rehabilitasi/penanaman bukan data berhasil bertahan hidup dari mangrove. Selain itu, penyebab lain dapat diduga dari ketepatan digitasi saat pengukuran lewat image satelit sehingga menyebabkan perbedaan antara luas hutan mangrove eksisting di lapangan dengan luas hutan mangrove hasil digitasi.

Khusus untuk upaya rehabilitasi hutan mangrove, kemungkinan bertahan hidup saat penanaman dengan kondisi eksisting akan berbeda. Berdasarkan penelitian Setyawan dkk (2006), kesalahan pemahaman pola hidrologi, perubahan arus laut, tipe tanah, pemilihan spesies, penggembalaan hewan ternak, sampah, kelemahan manajemen, dan ketiadaan partisipasi masyarakat 
dapat menjadi penyebab kegagalan program rehabilitasi hutan mangrove. Lebih lanjut, Setyawan dkk (2006) menyatakan bahwa dalam program restorasi/rehabilitasi hutan mangrove, sampah domestik seperti lembaran plastik, kantung plastik, tali dan lain-lain dalam menjadi masalah karena menutupi area penanaman sehingga anakan mangrove tidak dapat tumbuh sempurna, bahkan dapat menyebabkan seedling yang perakarannya masih lemah ikut terhanyut ke laut.

Saran dalam penelitian Rusdianti dkk (2012) untuk konversi lahan hutan mangrove serta upaya penduduk lokal dalam merehabilitasi ekosistem mangrove yaitu 1) konversi lahan dengan tujuan pembangunan maupun kesejahteraan penduduk merupakan salah satu alternatif yang bisa dilakukan penduduk. 2) Perlu dilakukannya penyuluhan maupun pelatihan dari kelompok yang bekerjasama dengan Pemerintah Desa dengan tujuan memberikan motivasi dan meningkatkan partisipasi kepada penduduk dalam kegiatan rehabilitasi mangrove. 3) Perlu adanya ketegasan Pemerintah Desa dalam mensosialisasikan Peraturan Desa yang membahas fungsi dan manfaat mangrove kepada penduduk lokal.

Novianty dkk (2012) menyatakan dalam penelitiannya di pantai utara Kabupaten Subang bahwa prioritas utama dalam memperbaiki kerusakan dan upaya rehabilitasi mangrove adalah menjalin kerjasama yang sinergis antara pelaksanaan program pemerintah dengan keinginan masyarakat lokal melalui revitalisasi kawasan pesisir akibat abrasi dengan cara penanaman kembali pohon mangrove. Pola rehabilitasi yang digunakan untuk mangrove dalam kriteria rusak (sedang) menggunakan pola empang parit dan mangrove dalam kriteria rusak berat (jarang) menggunakan pola green belt. Tambak sistem empang parit merupakan tambak yang pelataraannya berada diantara parit, hanya saja pelataran tersebut ditanami oleh mangrove dan pengairannnya diatur hanya dengan satu buah pintu air.

\section{Keterkaitan Hutan Mangrove dengan Produksi Ikan Laut Segar}

Keberadaan hutan mangrove erat kaitannya dengan keberlangsungan hidup biota laut salah satunya ikan, karena hutan mangrove menjadi salah satu tempat memijah dan berkembang bagi ikan. Untuk melihat keterkaitan hutan mangrove dengan produksi ikan laut maka disajikan data produksi ikan laut segar di Kabupaten Pati, khususnya untuk Pati utara. Produksi ikan segar di Pati Utara disajikan pada Tabel 6. Secara umum dari data perkembangan Produksi ikan menunjukkan adanya peningkatan pada tahun 2012, mengalami penurunan pada tahun 2013 dan mengalami penurunan kembali pada tahun 2014, sedangkan untuk tahun 2015 mengalami peningkatan. Khusus Kecamatan yang masuk dalam lokasi penelitian ini yaitu Tayu dan Dukuhseti terdapat TPI Margomulyo dan Sambiroto di Kecamatan Tayu, TPI Banyutowo dan Puncel di Kecamatan Dukuhseti. Produksi ikan laut segarnya jika dibandingkan produksi ikan segar secara umum di Kabupaten maka menurun dari $3,55 \%$ menjadi $2,52 \%$ tahun 2012; meningkat sedikit pada tahun 2013 menjadi $3,01 \%$ dan meningkat kembali sebesar $5,61 \%$ pada tahun 2014; kemudian turun kembali pada tahun 2015 yaitu $3,87 \%$. 
Tabel 6.

Produksi Ikan Segar Kabupaten Pati

\begin{tabular}{lrrrrr}
\hline \multirow{2}{*}{ Lokasi } & \multicolumn{5}{c}{ Tahun ( Kg ) } \\
\cline { 2 - 6 } & \multicolumn{1}{c}{$\mathbf{2 0 1 1}$} & $\mathbf{2 0 1 2}$ & $\mathbf{2 0 1 3}$ & $\mathbf{2 0 1 4}$ & \multicolumn{1}{c}{$\mathbf{2 0 1 5}$} \\
\hline TPI Pati Utara & & & & & \\
Margomulyo Tayu & 4.350 & 1.846 & 4.747 & 7.120 & 2.581 \\
Sambiroto Tayu & 12.236 & 5.692 & 10.521 & 3.716 & 1.724 \\
Banyutowo Dukuhseti & 1.249 .666 & 954.923 & 803.441 & 762.606 & 787.660 \\
Puncel Dukuhseti & 108.730 & 114.707 & 149.939 & 131.840 & 242.206 \\
\hline Total Pati Utara & 1.374 .982 & 1.077 .168 & 968.648 & 905.282 & 1.034 .171 \\
Rata-rata Pati Utara & 343.746 & 269.292 & 242.162 & 226.321 & 258.543 \\
Kabupaten Pati & 38.718 .048 & 42.818 .986 & 32.170 .803 & 16.143 .036 & 26.710 .118 \\
\% Pati Utara & 3,55 & 2,52 & 3,01 & 5,61 & 3,87 \\
\hline Surayyyyyy
\end{tabular}

Sumber : BPS Kab. Pati, 2012-2015

Keterkaitan antara perkembangan hutan mangrove dengan produksi ikan laut segar di Pati Utara dapat dilihat pada Gambar 7. Gambar 7 menunjukkan bahwa produksi ikan segar di wilayah Pati utara hampir sejalan dengan perkembangan mangrove lokasi penelitian yaitu penurunan produksi ikan bersamaan dengan penurunan perkembangan mangrove, sedangkan peningkatan kembali perkembangan mangrove di tahun berikutnya diiringi dengan peningkatan produksi ikan segar di wilayah Pati Utara.

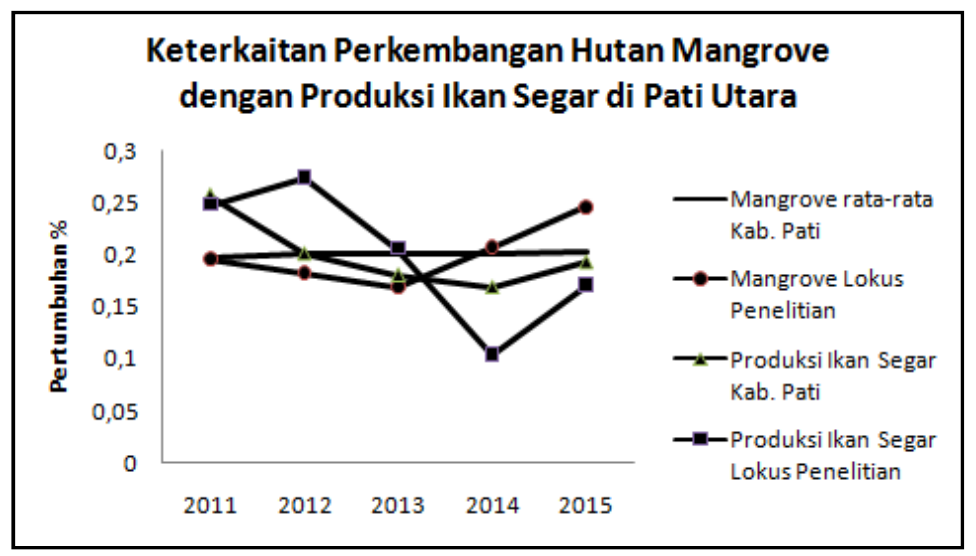

Gambar 7.

Keterkaitan Perkembangan Hutan Mangrove dengan

Produksi Ikan Laut Segar di Pati Utara

Sumber : Pengolahan Data, 2017

\section{KESIMPULAN DAN SARAN}

\section{Kesimpulan}

Kesimpulan pada penelitian ini adalah 1) perkembangan mangrove di Pati utara kondisi berkembang buruk; 2) perkembangan mangrove di Pati utara mengalami penurunan pada tahun 2013 dan meningkat kembali pada tahun 2015 dan 2017; 3) perkembangan mangrove diiringi dengan peningkatan produksi ikan segar di Pati Utara.

\section{Saran}

Saran penelitian ini yaitu mempertahankan dan meningkatkan 
perkembangan mangrove dan meminimalisir bertambahnya penghalang pertumbuhan mangrove (pertambakan).

\section{DAFTAR PUSTAKA}

Badan Pusat Statistik Kabupaten Pati. (2012). Pati Dalam Angka Tahun 2011. Pati

Badan Pusat Statistik Kabupaten Pati. (2013). Pati Dalam Angka Tahun 2012. Pati

Badan Pusat Statistik Kabupaten Pati. (2014). Pati Dalam Angka Tahun 2013. Pati

Badan Pusat Statistik Kabupaten Pati. (2015). Pati Dalam Angka Tahun 2014. Pati

Badan Pusat Statistik Kabupaten Pati. (2016). Pati Dalam Angka Tahun 2015. Pati

Damayanti, H. O. (2011). Kajian Model Hidrodinamika dengan Menggunakan Data Constant dan Transient. Jurnal Litbang, VII(1), 23-31

Jumaedi, S. (2016). Nilai Manfaat Hutan Mangrove dan Faktor-Faktor Penyebab Konversi Zona Sabuk Hijau (Greenbelt) Menjadi Tambak di Wilayah Pesisir Kota Singkawang Kalimantan Barat. Jurnal Sosiohumaniora, 18(3), 227-234.

Kawaroe, M. (2001). Kontribusi Ekosistem Mangrove Terhadap Struktur Komunitas Ikan di Pantai Utara Kabupaten Subang, Jawa Barat. Jurnal Pesisir dan Lautan, 3(3), 12-25.

Keputusan Presiden Republik Indonesia Nomor 32 Tahun 1990 tentang Pengelolaan Kawasan Lindung.

Novianty, R., Sastrawibawa, S., Prihadi, D. J. (2012). Identifikasi Kerusakan dan Upaya Rehabilitasi Ekosistem Mangrove di Pantai Utara Kabupaten Subang. Jurnal Perikanan dan Kelautan, 3(1), 4147.

Rusdiyanti, K., Sunito, S. (2012). Konversi Lahan Hutan Mangrove Serta Upaya Penduduk Lokal dalam Merehabilitasi Ekosistem Mangrove. Jurnal Sosiologi Pedesaan, 6(1), 117.

Sari, S., Pratomo, A., Yandri, F. (2013). Hubungan Kerapatan Mangrove Terhadap Kelimpahan Pelecypoda di Pesisir Kota Rebah Kota Tanjungpinang. Jurnal Universitas Maritim Raja Ali Haji. http://jurnal.umrah.ac.id/?tag=keli mpahan\&paged $=2, \quad$ diakses 30 Oktober 2017.

Setyawan, A. D., Winarno. K. (2006). Permasalahan Konservasi Ekosistem Mangrove di Pesisir Kabupaten Rembang, Jawa Tengah, Jurnal Biodeversitas, 7(2), 159-162.

Wardhani, M. K. (2011). Kawasan Konservasi Mangrove : Suatu Potensi Ekowisata. Jurnal Kelautan, 4(1), 60-76.

Yuniarti. (2007). Pengelolaan Wilayah Pesisir Indonesia (Studi Kasus : Pengelolaan Terumbu Karang Berbasis Masyarakat di Kepulauan Riau). Makalah. Fakultas Perikanan dan Ilmu Kelautan. Jatinangor : Universitas Padjadjaran.

\section{BIODATA PENULIS}

Hermain Teguh Prayitno, lahir 11 April 1970 di Rembang Jawa Tengah. Magister Ilmu Lingkungan dari Universitas Diponegoro Semarang. Saat ini bekerja sebagai peneliti di Badan Perencanaan Pembangunan Daerah Kabupaten Pati. 